\title{
An update of coronavirus disease 2019 (COVID-19): an essential brief
}

\author{
Afshin Zare ${ }^{1}$, Seyyede Fateme Sadati-Seyyed-Mahalle ${ }^{1}$, \\ Amirhossein Mokhtari ${ }^{1}$, Nima Pakdel ${ }^{1}$, Zeinab Hamidi ${ }^{1}$, \\ Sahar Almasi-turk ${ }^{2}$, Neda Baghban ${ }^{1}$, Arezoo Khoradmehr ${ }^{1}$, \\ Iraj Nabipour ${ }^{1}$, Mohammad Amin Behzadi ${ }^{3, *}$, Amin \\ Tamadon ${ }^{1, *}$
}

1. The Persian Gulf Marine Biotechnology Research Center, The Persian Gulf Biomedical Sciences Research Institute, Bushehr University of Medical Sciences, Bushehr, Iran

2. Department of Anatomical Sciences, School of Medicine, Bushehr University of Medical Sciences, Bushehr, Iran

3. Department of Vaccine Discovery, Auro Vaccines LLC, Pearl River, New York, United State

\section{KEYWORDS}

SARS-CoV-2;

COVID-19;

Epidemiology;

Pathology;

Clinical;

Vaccines

Article Info

Received 2021/06/18;

Accepted 2021/07/04;

Published Online 2021

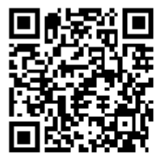

\section{ABSTRACT}

During 2019, the number of patients suffering from cough, fever and reduction of WBC's count increased. At the beginning, this mysterious illness was called "fever with unknown origin" but now, it is known as the 2019 novel coronavirus (2019$\mathrm{nCoV}$ ) or the severe acute respiratory syndrome corona virus 2 (SARS-CoV-2). The SARS-CoV-2 is one member of great family of coronaviruses. Coronaviruses are enveloped positive-stranded RNA viruses. The SARS-CoV-2 has some particular structures for infecting, reproducing and causing damage. The SARS-CoV-2 can bind angiotensin-converting enzyme 2 (ACE-2) receptors and cause various difficulties for human. The SARS-CoV-2 can cause both serious and not-serious issues for mankind. Malayan pangolin and bat are the most suspicious candidate for being sources of the SARS-CoV-2. The SARS-CoV-2 can be transmitted by various ways such as transmitting from infected human to healthy human and can make severe pneumonia, which can lead to death. The SARS-CoV-2 can infect different kind of people with different ages, races, and social and economic levels. The SARSCoV-2 infection can cause various sorts of clinical manifestations like cough and fever and intensity of signs and symptoms depends on sufferer conditions. Clinicians use all of available documents and tests for diagnosing new cases and curing patients with high accuracy. At the present time, there is no particular way for treating SARSCoV-2 infection. It seems that the best way for standing against the SARS-CoV-2 infection is preventing from it by social distancing and vaccination. This review tries to prepare an essential brief update about SARS-CoV-2 infection.

\footnotetext{
Corresponding Information: Amin Tamadon, The Persian Gulf Marine Biotechnology Research Center, The Persian Gulf Biomedical Sciences Research Institute, Bushehr University of Medical Sciences, Bushehr, Iran; Postal Code: 7514633196; Tel/fax: +98-77-3332-8724; Email: amintamaddon@yahoo.com

Mohammad Amin Behzadi, Department of Vaccine Discovery, Auro Vaccines LLC, Pearl River, New York, United State;Email: mbehzadi@aurovaccines.com
}

Copyright (C) 2021. This is an open-access article distributed under the terms of the Creative Commons Attribution-noncommercial 4.0 International License which permits copy and redistribute the material just in noncommercial usages, provided the original work is properly cited.

\section{Abbreviations}

2019-nCoV, 2019 novel coronavirus; ACE-2, Angiotensin-converting enzyme 2; BCG, Bacillus calmette-guérin; COPD, Chronic obstructive pulmonary disease; COVID-19, Coronavirus disease 2019; E proteins, Envelope proteins; FDA, Food and drug administration; HE, Hemagglutinin-esterase; M proteins, Membrane proteins; MERS, Middle East respiratory syndrome; MERS-COV, Middle east respiratory syndrome coronavirus; mRNA, Messenger RNA; N proteins, Nucleocapsid proteins; NSPs, Non-structural proteins; RBD, Receptor-binding domain; RDS, Respiratory distress syndrome; RTC, Transcription-replication complex; S protein, Spear-like proteins; SARS, Severe acute respiratory syndrome; SARS-COV, Severe acute respiratory syndrome coronavirus; SARS-CoV-2, Severe acute respiratory syndrome corona virus 2; UK, United Kingdoms; WBC, White blood cell; WHO, World Health Organization 


\section{Introduction}

Reports demonstrate an increasing trend in number of sufferers with fever, cough and deduction in white blood cell count at the end of 2019. "Fever with unknown origin" was chosen for the name of this mysterious illness (1). Based on different documents including clinical characteristics, various analysis of body fluid samplings and radiological examinations, this illness was known as viral pneumonia by clinicians (2). Nowadays, "the 2019 novel coronavirus (2019-nCoV), coronavirus disease 2019 (COVID-19), or the severe acute respiratory syndrome corona virus2 (SARS-CoV-2)" has been chosen for this infection (3).

The SARS-CoV-2 is a member of the vast family of coronaviruses (2). The SARS-CoV-2 can bind angiotensin-converting enzyme-2 (ACE-2) receptors and cause various difficulties for human including either not-serious issues like fever and cough or serious concerns such as multi-organ failure (2). The SARS-CoV-2 has high potential to transmit between human to human and it has the ability to make severe pneumonia, which can eventually kill humans (3). The SARS-CoV-2 has high potential to infect human and after a short time it revealed in Wuhan, China, it has spread all over the world. Therefore, in January 30, 2020, WHO announced that the SARS-CoV-2 infection is a worldwide issue and a global emergency situation because this infection threats human life (3).

At the present time, health care providers don't have any particular curative method for treatment of the SARS-CoV-2 infection; neither antiviral drugs nor palliative agents (4). Symptomatic treatment strategies are recommended for clinical practice (5). In addition, several drugs with potential therapeutic ability such as dexamethasone and remdesivir have been evaluated for the treatment of the SARS-CoV-2 (4). However, as we mentioned before, no antiviral agents have yet been proved to be beneficial for the SARS-CoV-2 infection (6). The aim of the present review was to give a general overview about this new virus considering essential brief for clinicians.

\section{Virology of SARS-CoV-2}

Coronaviruses are enveloped positive-stranded RNA viruses (7). Coronaviridae family (order Nidovirales) has a subfamily called Orthocoronavirinae (8). Orthocoronavirinae include four type of CoVs: Alphacoronavirus (alpha-CoV), Betacoronavirus
(beta-CoV), Deltacoronavirus (delta-CoV), and Gammacoronavirus (gamma-CoV) (8). The SARSCoV-2 belongs to of Betacoronaviruses (9). These viruses are spherical, oval, or pleomorphic with a diameter of about 60-140 nm (10). SARS-CoV-2's structure consists of genome (RNA), nucleocapsid, membrane protein $(\mathrm{M})$ and the envelope $(\mathrm{E})$ protein (2) (Figure 1).

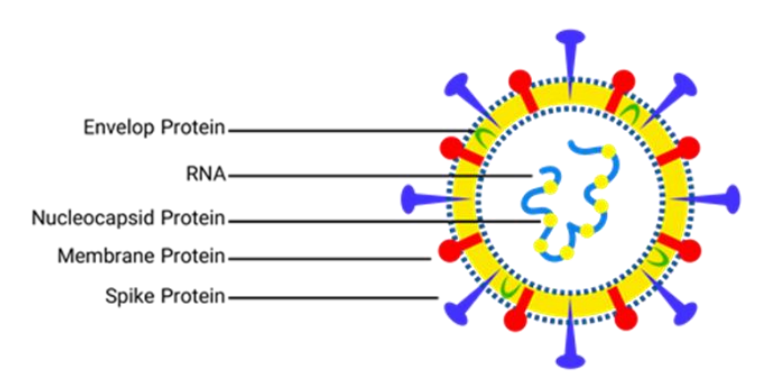

Figure 1. Structure of severe acute respiratory syndrome corona virus 2 (SARS-CoV-2).

Two-third of viral RNA is finally translated into two polyproteins, pp1a and pp1ab, and 16 non-structural proteins (NSPs), while other parts of the genome encoding subsidiary and structural proteins (11) (Figure 2). In the other words, the remainder of the virus genome encodes four basic structural proteins, including the spear-like proteins (S protein), membrane proteins ( $\mathrm{M}$ proteins), envelope proteins (E proteins), and nucleocapsid proteins ( $\mathrm{N}$ proteins) (11). The SARSCoV-2 major particles contain genome, spear-like appendages (S protein), non-structural proteins (NSPs), and envelope (10) (Table 1).

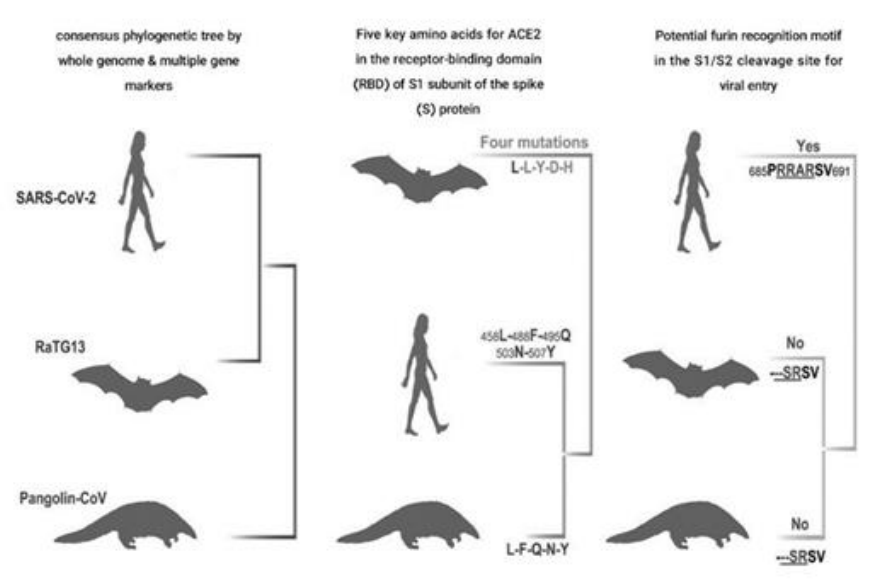

Figure 2. Pathophysiology of severe acute respiratory syndrome corona virus 2 (SARS-CoV-2). 
Table 1. The important parts of severe acute respiratory syndrome corona virus 2 (SARS-CoV-2)

\begin{tabular}{lll}
\hline Viral element & Function & References \\
\hline Genome (RNA) & Transcripting and translating & $(8)$ \\
& structural and non-structural \\
& proteins \\
& Block the host innate immune \\
NSPs & response \\
& Promotes viral assembly and \\
Envelope & release \\
& Guiding virus to host receptors \\
Spear-like structure & binding to the ACE-2 receptor \\
& in the lungs and other tissues
\end{tabular}

ACE-2, Angiotensin-Converting Enzyme 2; NSPS, NonStructural Proteins.

The nucleocapsid is located deeply inside phospholipid bilayers and coated by two diverse sorts of spear-like proteins: the spear-like glycoprotein trimmer (S) and the hemagglutinin-esterase (HE) and the sites between the $\mathrm{S}$ proteins are filled by the membrane protein $(\mathrm{M})$ and the envelope $(\mathrm{E})$ protein in the viral envelope (12). The SARS-CoV-2 has spearlike structure made from glycoprotein (Glycoprotein S) and this spear-like structure causes binding SARSCoV-2 to the ACE-2 receptor on the surface of human cells (13). The glycoprotein $S$ contains of two portions, S1 and S2 (14). The S1 divided into three domains, A, B and C (15). The domain A of the S1 for plays role in binding to the host receptors and the domain B has duty to facilitate the entry of SARSCoV-2 into target cells (11). The S2 causes modulating of fusion between the virus and the host cell (16).

After membrane fusion, viral genome (RNA) releases into the cytoplasm of the host cell and this uncovered RNA starts to translate two polyproteins: ppla and pplab (17). These two polyproteins, pp1a and pplab, encode non-structured proteins (NSPs) and form the transcription-replication complex (RTC) within a dual-membrane vesicle (18). The RTC then replicates and transcribes a set of nested RNAs that encode accessory and structural proteins (19). By means of endoplasmic reticulum and Golgi's body, recently formed RNAs, nucleocapsid proteins and glycoproteins of the viral coat are collected and form the particles of the virus. Finally, the vesicles comprising the virus combine with the plasma membrane for releasing the virus (20).

\section{Origin of SARS-CoV-2}

The primitive surveys demonstrated that the first cases who suffer from the SARS-CoV-2 infection had been reported from local Huanan seafood market (2). Although SARS-CoV-2 was extracted from Huanan seafood market, the origin of the SARS-CoV-2 is under debate because the first SARS-CoV-2 case reported had no connection to the mentioned market (21). Moreover, it was discovered that at least two diverse types of the SARS-CoV-2 had been officially reported before COVID-19 and recent surveys presented that the SARSCoV-2 may imported from other sites to Huanan seafood market (22).

Coronaviruses, first found in the 1960s, have been found in birds and mammals, including in camels, bats and rats (23). SARS-CoV-2 has a single-stranded positive-sense RNA genome, which has 74 to $99 \%$ similarity with coronavirus from the pangolin (Manis javanica) (24). One portion of spear-like protein (S protein) called receptor-binding domain (RBD) in pangolin-CoV has only one different amino acid compared with that of SARS-CoV-2. In addition, the infected pangolins show pathological symptoms as same as humans infected with COVID-19 and the antibodies in their blood are able to react with the spike protein of SARS-CoV-2 (25). Accordingly, the pangolin is considered as one of the probable intermediate hosts between bat and human (24) (Figure 3).

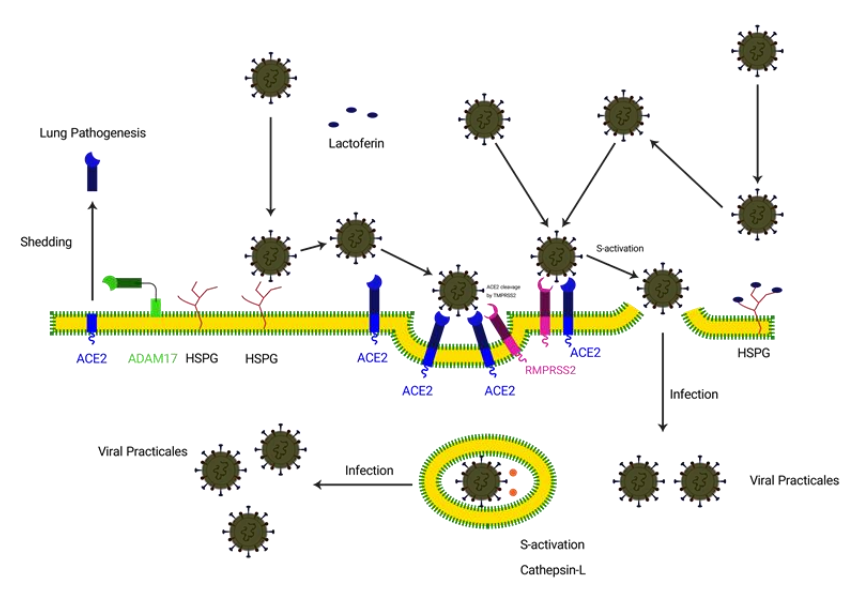

Figure 3. Origin of severe acute respiratory syndrome corona virus 2 (SARS-CoV-2). 


\section{An update of coronavirus disease 2019...}

On the other hand, bats have been introduced as the remarkable origin of coronaviruses (26). SARS-CoV2's genome has $99 \%$ similarity with that of horseshoe bat (Rhinolophus sinicus) (Bat-CoVRaTG13) (24). Although, the genome of coronavirus separated from bat has approximately $96 \%$ identity with SARS-CoV2 , its receptor-binding domain (RBD) is different compared to that of the later, showing a low potential to bind to the human ACE-2 (27). Recently, SARSCoV-2 has been suggested as a modified coronavirus originated from bat transmitting to humans through zoonotic transmission (28). Other animals were under investigation as the possible intermediate hosts of SARS-CoV-2 like snakes, minks and turtles (29).

Five out of the six major amino acids in the structure of the RBD of the S-protein from SARS-CoV and SARS-CoV-2 are different, unlike the theories on the laboratory origin of SARS-CoV-2 by manipulating other coronaviruses (30). Different surveys demonstrated that SARS-CoV-2 is an animal virus transmitted to humans through undergoing evolutionary adaptations (31). Analysis of different studies has suggested that SARS-CoV-2 formed by recombining the pangolin- $\mathrm{CoV}$ and the bat-CoVRaTG13-like virus (32). However, more studies are needed for confirming the intermediate hosts of coronaviruses for stopping zoonotic transmission and avoiding the outbreak of such viral infections in feature (33).

\section{Mutant type(s) of SARS-CoV-2}

Mutation rate in RNA viruses is extensively high and this rate is associated with virulence modulation and evolvability, behaviors considered to be useful for viral adaptation (34). Early reported studies demonstrated that fast spread of SARS-CoV-2 across world and emergence of the genomes containing new mutation hotspots. Mutation rate of RNA virus plays role in viral adaptation making equilibrium between the integrity of various genetic data and genome variability (35).

Biological characterization of viral mutations can supply valuable intuitions for evaluating immune escape, viral drug resistance, immune escape and pathogenesis dependent mechanisms. In addition, it can be vital for drafting new vaccines, antiviral medications and diagnostic tests (36). Therefore, it seems to be necessary to know about mutant types of SARS-CoV-2.
In late January or early February 2020, a mutant type of SARS-CoV-2 was appeared that has D614G replacement in the gene encoding the spike protein. This new strain became dominant type of SARS-CoV-2 in china and spread globally after a short period of time (37). Researches revealed that compared to the initial virus strain, this new class of SARS-CoV-2 has enhanced transmission and infectivity (38). The SARSCoV-2 virus with the D614G replacement does not make more intense illness or change the efficacy of current laboratory diagnostics, medications, vaccines, or public health preventative criteria (39).

First mutant strain of SARS-CoV-2 United Kingdom was observed in Wales on September and midNovember that was called 501Y lineage (501Y Variant 1). After that, on 14 December 2020, second mutant strain was reported in United Kingdom and named SARS-CoV-2 VOC 202012/01 (Variant of Concern, year 2020, month 12, variant 01 or 501Y Variant 2, also named as B.1.1.7). In November/December 2020, this new strain has also become the predominant strain in England (40). This mutant strain includes 23 nucleotide replacements and is not phylogenetically linked to the SARS-CoV-2 virus circulating in the United Kingdom at the time the mutant type was identified. According to surveys, SARS-CoV-2 VOC 202012/01 is more transmittable than early virus strain and it has the capability of reinfection. Although infectivity of this new strain is not obvious (41). Moreover, origination of SARS-CoV-2 VOC 202012/01 is unclear (40).

On 18 December 2020, South African government declared the discovery of a new mutant type of SARS$\mathrm{CoV}-2$, which quickly spread in three provinces of South Africa. Because of a N501Y mutation, South Africa named this variant 501Y.V2, on the other hand, SARS-CoV-2 VOC 202012/01, which was detected in UK, also has the N501Y mutation, but phylogenetic analysis has demonstrated that 501Y.V2 originating from South Africa is different from mentioned strain in UK (42). Recent surveys revealed that 501Y.V2 is more transmittable in comparison to early strain. In addition, studies showed that this new strain has high affinity to human ACE-2 receptor (43). Furthermore, mutation in this new strain gives ability to stabilize viral bindings with ACE-2 receptor (44) as well as ability to escape from human immune system (45). The severity of infection caused by this new viruses is under investigation (45). 


\section{Transmission of SARS-CoV-2}

Symptomatic patients with coronavirus are the most important distributors; but asymptomatic patients can be one of the important source of viral transmission (46). Transmission through close person-to-person contact, hand shaking, touching contaminated surfaces, contaminated hand contact with eyes, mouth and ears, respiratory droplets and wound, and oralfecal transmission are known as viral transmission routes (47).

Vertical transmission from mother to infant has been reported (48), but, no intrauterine vertical transmission has been reported for any infant with SARS and MERS in the past $(49,50)$. In addition, based on all available data, amniotic fluid, umbilical cord blood, neonatal pharyngeal swab and breast milk samples from six newborns born by infected mothers were examined for SARS-CoV-2 and all cases were negative for the virus (51).

\section{Epidemiology of SARS-CoV-2}

In a study conducted in China in 2020 on 44,672 patients, it was obtained that the highest number of patients ranged between 50 to 59 years. The lowest number of patients was in the age range of 0 to 9 years. In addition, mentioned survey revealed that occupationally, patients who were retired, workers, and farmers, had the highest incidence of the disease. Additionally, most patients had a mild form of the illness. In addition, the mortality rate was higher in men than women, retirees had the highest mortality rate, age group $\geq 80$ showed the highest mortality rate among all age groups, the mortality rate in patients who had other underlying disease in addition to SARS-CoV2 infection was much higher than in patients without underlying disease. Among patients with underlying problems (cardiovascular disorder, diabetes, chronic respiratory disorder, hypertension and cancer) and patients with cardiovascular problems have the highest mortality rate because of SARS-CoV2 infection (52).

Data obtained from various studies to date show that in general, different age groups are susceptible to SARS-CoV-2. However, ACE-2 is significantly expressed more in Asian populations than European and American populations, and ACE- 2 in male cells is higher compared to the female cells that may partly justify the fact that the incidence of coronavirus pneumonia is higher in men and in Asia.
The elderly and people with the disease are more probable to progress a severe and fatal form of the illness. The most common underlying problems that predispose a person to SARS-CoV-2 infection are cardiovascular disorder, hypertension, diabetes, and chronic obstructive pulmonary disease (COPD) (47). Severe complications that this disease can cause in individuals include respiratory distress syndrome (RDS), septic shock and metabolic acidosis that respond poorly to treatment and cause multiple organ failure and coagulation problems (47).

\section{Pathophysiology of SARS-CoV-2}

SARS-CoV-2 uses ACE-2 receptors to transport itself to human cells (53). The fluid obtained from bronchoalveolar lavage of a SARS-COV-2 patient demonstrated that SARS-CoV-2 enters in human cells by using the ACE-2 receptors (31). ACE-2 is a surface molecule that is extensively expressed in different regions of human body include lung AT2 cells, upper esophageal epithelial cells, and enterocytes in the ileum and colon so this fact demonstrates a high potent passage in the gastrointestinal and respiratory tract for SARS-CoV-2 virus (53). Different organs of human body can be affected by SARS-CoV-2 infection (8). ACE-2, found in the lower portion of human respiratory tract, is known as a receptor for SARS-CoV-2 and regularizes human-to-human and cross-species viral transmission (54).

\section{Diagnosis of SARS-CoV-2}

SARS-COV-2 is diagnosed based on history taking, radiographic images, and detailed laboratory tests (55). Current diagnostic tools include nucleic acid testing or virus genome detection (55). Samples included nasopharyngeal swabs, sputum, lower respiratory tract secretions, blood, and feces (55). The nasopharyngeal swab is the most common example; however, the number of positive cases is less than 50\% (55). Repeated diagnostic testing is necessary to increase diagnostic accuracy (55). The number of positive cases in bronchoalveolar lavage fluid was high; however, this method is not suitable for most patients due to the increased risk of cross-infection (55).

\section{Clinical manifestations}

The incubation period of COVID-19 has been estimated 1 to 14 days and the average of 8 days (56). Fever and cough has been reported as the most common symptoms, while upper respiratory symptoms and gastrointestinal have been rarely reported as the symptoms of this disease (57). 
24 An update of coronavirus disease 2019...

SARS-CoV-2 infection can cause various sorts of clinical manifestations depends on patient situation (Table 2 and Figure 4).

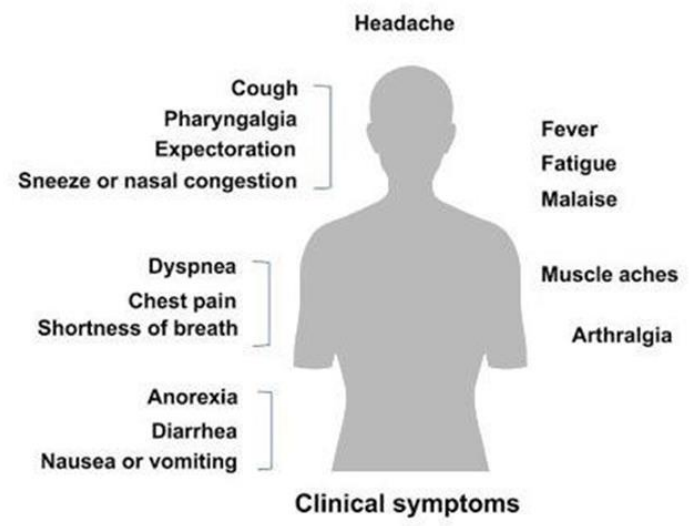

Figure 4. Clinical manifestation of severe acute respiratory syndrome corona virus 2 (SARS-CoV-2).

Table 2. Clinical manifestations of severe acute respiratory syndrome corona virus 2 (SARS-CoV-2) in different surveys

\begin{tabular}{ll}
\hline Clinical manifestations & References \\
\hline General symptoms: & $(102)$ \\
Fever & Cough \\
& Fatigue \\
& Sputum production \\
& Shortness of breath \\
& Sore throat \\
& Headache \\
Gastrointestinal symptoms: & Diarrhea \\
Nausea & Vomiting \\
Abdominal pain & Hematemesis \\
Hematochezia/melena & Constipation \\
Severe symptoms: \\
Acute respiratory distress syndrome \\
\hline
\end{tabular}

\begin{tabular}{l}
\hline Neurologic symptoms: \\
Headache \\
Vision changes \\
Altered mental status \\
Meningitis signs \\
Cranial nerve palsy \\
Cardiac signs: \\
Abnormalities on echocardiogram \\
Dysrhythmia \\
Scarce symptoms: \\
Rash \\
Conjunctivitis \\
Strawberry tongue \\
Tongue or mouth ulcers \\
Tongue enlargement \\
Geographical tongue \\
Cracked lips \\
\hline
\end{tabular}

\section{SARS-CoV-2 in pregnant woman}

COVID-19 has been spreading rapidly since 2019 , and we have had many cases since then, but our knowledge about the clinical manifestations and treatment of COVID-19 in pregnant woman is very limited (58). Pregnant women are a high-risk group during an infectious disease epidemic (59).The exact infected maternal mortality rate dose not determined yet (60). According to a research on 118 infected pregnant woman in Wuhan, fever and cough are the most common symptom of COVID-19 in pregnancy (presented in $\% 75$ of patients) (61). Forty-four percent of patient presented lymphopenia. Ninety-three pecent of patients gave birth by cesarean section most of them was due to concern about COVID-19. The study on six patients was negative for transmission of the virus through breast milk but we are worried about transmission of virus by respiratory secretions and droplets in close contact that infected mother and neonate have during the breast feeding (62). Severe respiratory disease in infected neonate is rare and if it happen, it's unclear that infection occurred in utero or after the birth (63). According to researches on vertical corona virus transition in two small clinical series research there is no evidence that COVID-19 can transfer vertically from mother to fetus (62). Researches show that, delaying in clamping of umbilical cord doesn't increase risk of COVID-19 transition (62). 
Although we are not concern about vertical transmission COVID-19 to fetus, but neonate could be infected via respiratory secretion of infected mother, because of that infected mother and neonate should be physically separated. Factors like prematurity and fatal distress should be considered during the separation (64). Maternal illness can cause other clinical findings (respiratory distress, thrombocytopenia, death and etc.) in neonates, for example in one clinical series research approximately $60 \%$ of neonates with infected mother have abnormal clinical findings in their early life (62). The rate of preterm birth in an infected mother is much higher than the general population, and most were iatrogenic due to the maternal condition (65). There is no difference between vaginal delivery and caesarean section for infected mothers and decision should be based on the individualized basis (60). There is no evidence that COVID-19 is teratogenic or increases the chance of miscarriage (60). Changes in the immune system allow the allogeneic fetus to grow during pregnancy (63). The immune system of pregnant women is modulated. This modulation may affect how the immune system responds to the virus (66). Pregnancy causes changes in lung functions and a decrease in total lung capacity. These factors make a pregnant women more prone to severe respiratory infections (63). According to research on 118 pregnant woman risk of severity of COVID-19 in pregnant women is lower than normal population but respiratory disease like COVID-19 can exacerbate after giving birth because of pathophysiological changes (67). Current gold standard for detecting SARS-CoV-2 is real-time reverse transcriptase-polymerase chain reaction assay (60). If necessary, a CT scan should be performed on the pregnant woman (60).

Treating a pregnant woman has too many challenges. For example, mechanical ventilation, experimental treatment, prescribing certain drugs and early termination of pregnancy due to maternal condition (60). If a pregnant COVID-19 patient needs to be admitted, the infected mother should be isolated from non-infected patients and then assess vital signs, request laboratory data, and prescribe paracetamol and anticoagulants (60). Evaluate patient's condition, if it's worsens, consider ICU admission, IV fluid therapy, oxygen therapy, empirical antibiotics for pneumonia and invasive ventilation (60). Azithromycin is safe during pregnancy and could be prescribed to breastfeeding mothers (68).
Remdesivir is currently used to treat COVID-19, but our information about its effects on pregnancy is limited, a research on an 86 infected pregnant and postpartum women shows that Remdesivir can be effective and increase rate of recovery (69). Treatment with methylprednisolone is recommended in recent guidelines in non-pregnant patients with moderate acute respiratory distress syndrome (70). A study of 454 nonpregnant women with COVID-19 infection treated with corticosteroids revealed that giving dexamethasone to non-pregnant women significantly reduced mortality, need for mechanical ventilation and oxygen support (70). It is best to administer corticosteroids that have lowest rate of placental transfer and minimal mineralocorticoid effects and highest lung tissue penetration, like Methylprednisolone (70). Numerous studies have shown that giving corticosteroids for preterm labor significantly reduces complications and mortality of neonates by inducing fetal lung maturation (70). Steroid therapy should be given to pregnant women with COVID-19 who need mechanical ventilation or oxygen therapy, or both (70). If glucocorticoids are not required for fetus lung maturation and are prescribed only for the treatment of COVID-19, prescription of methylprednisolone for 10 days is enough. When we want to prescribe corticosteroids for fetal lungs maturation and treatment of COVID-19, it is best to start with a two days course of dexamethasone and then give the patient a 10-days course of prednisolone (70). Patients with COVID-19 infection are at higher risk for thromboembolic events compare to normal population and pregnancy is a hypercoagulable state because of that guidelines recommend that prophylaxis for thromboembolism should be given during the pregnancy until 10 days after giving birth (71).

\section{SARS-CoV-2 in neonates}

Infants and neonates are affected by COVID-19 less than adults. Although major passages for infecting neonates like intrauterine or perinatal ways remains unclear and vertical transmission should be examined more, but some surveys demonstrated infection by COVID-19 via vertical transmission and respiratory droplets at the time of exposing newborn contact with mother and operation room personnel (48). Symptoms in infants similar to others like: fever, coughing, sore throat, sneezing, fatigue, gastrointestinal problems like nausea vomiting Diarrhea abdominal pain, the have poor appetite and poor feeding (72). 
First line of treatment is oxygen therapy, water and electrolyte maintenance, nutritional support. Newborn with acute respiratory distress must treat with surfactant and nitric oxides and ventilation support. Intravenous immunoglobulin, corticosteroids and for those case who are presented with bacterial superinfection must treat with antibiotics (73).

\section{SARS-CoV-2 in children}

Based on study was performed in 2020, the average age of all patients was 7 years and $56.6 \%$ of all patients were boys. About $90 \%$ of the patients were asymptomatic, mild or moderate symptoms of COVID-19. The average time from sickness onset to recognize were 2 days. Only $4.4 \%$ of pediatric patients observed by sever disease. All ages children were presented disposed to COVID-19 and there was not expressive sex difference. Despite the fact clinical display of children's COVID-19 cases were chiefly less severe than adult patients. The dispensation of children's COVID-19 cases was different in time and space. Additionally, according to this study strong averment of human to human transmission. Most of infected children were transmitted by their family (74). About sign and symptoms, some surveys have showed that cough, fever, fatigue and breath shortness were the most common between patients and some of pediatric patients detected with digestive symptoms like nausea, vomiting and diarrhea (75). The first way to diagnose infected children Is taking sample from sputum, stool and blood. Checking level of bilirubin and hepatic enzymes in children showed severity of the disease. Also increase level of lymphocytes in blood known as severe symptoms in children. Lung imaging also is important to confirm the diagnosis. In some articles reported that symptoms of COVID-19 in children like Kawasaki's disease then heart problems must be considered (74). Patient must hospitalize in isolation negative air pressure room. First line of treatment is supportive care like fluid therapy and electrolyte management, antiviral drugs and respiratory care. Treatment for the patient in ICU include first line of treatment and combination of immunomodulator and anti-viral drugs such as oseltamivir and hydroxychloroquine and based on the patient's situation Antibiotics can be added (76).

\section{Laboratory examinations}

Laboratory examinations along with taking history and radiographic analysis are three bases for finding and curing COVID-19 sufferers (77).
Studies show different laboratory finding and we gathered different laboratory findings in Table 3.

Table 3. Laboratory finding $(s)$ in severe acute respiratory syndrome corona virus 2 (SARS-CoV-2)

\begin{tabular}{|c|c|c|}
\hline Laboratory finding(s) & Changes & References \\
\hline \multicolumn{3}{|l|}{ Early stage } \\
\hline Total WBC & $\begin{array}{l}\text { Normal or significantly } \\
\text { decreased }\end{array}$ & $(8,107,108$ \\
\hline Lymphocyte count & Significantly decreased & $(8,107,108$ \\
\hline \multicolumn{3}{|l|}{ In severe cases } \\
\hline Neutrophil count & Significantly increased & (47) \\
\hline D-dimer & Significantly increased & (47) \\
\hline Blood urea & Significantly increased & (47) \\
\hline Creatinine level & Significantly increased & (47) \\
\hline Lymphocyte count & Significantly decreased & (47) \\
\hline $\begin{array}{l}\text { IL-6, }-2,-7 \text {, and - } \\
10\end{array}$ & Significantly increased & $(11,21)$ \\
\hline TNF- $\alpha$ & Significantly increased & (11) \\
\hline LDH & $\begin{array}{l}\text { Normal or significantly } \\
\text { increased }\end{array}$ & $(8,109)$ \\
\hline Muscle enzymes & $\begin{array}{l}\text { Normal or significantly } \\
\text { increased }\end{array}$ & $(8,109)$ \\
\hline CRP & $\begin{array}{l}\text { Normal or significantly } \\
\text { increased }\end{array}$ & $(8,109)$ \\
\hline $\begin{array}{l}\text { Myocardial } \\
\text { enzymes }\end{array}$ & Normal & (109) \\
\hline \multicolumn{3}{|l|}{ ICU patients } \\
\hline GCSF & Significantly increased & (21) \\
\hline IP-10 & Significantly increased & (21) \\
\hline MCP-1 & Significantly increased & (21) \\
\hline MIP- $1 \alpha$ & Significantly increased & (21) \\
\hline TNF- $\alpha$ & Significantly increased & (21) \\
\hline
\end{tabular}

WBC, White blood cell count; IL, Interleukin; Tumor necrosis factor- $\alpha ; L D H$, Lactate dehydrogenase; $C R P, C$-reactive protein; GCSF, Granulocyte colony-stimulating factor; IP-10, $10 \mathrm{kDa}$ interferon-induced gamma protein; $M C P-1$, Monocyte 1; MIP$1 \alpha$, Macrophage

\section{Histopathological findings}

Autopsy of different cases infected by SARS-CoV-2, revealed that this virus can damage various organs; based on this fact, SARS-CoV-2 can cause diverse histopathological views in body organs (78). 
Although, histopathological findings are not certain documents for clinicians to make decision for patients suffering from COVID-19, but they give us remarkable information about pathological changes, pathogenesis of the disease, and the cause of death in COVID-19 cases (77). In Table 4, we discussed histopathologic changes in lung tissues after being infected by SARS-CoV-2.

Table 4. Pathological finding(s) in infected lung with severe acute respiratory syndrome corona virus 2 (SARS-CoV-2) (110114)

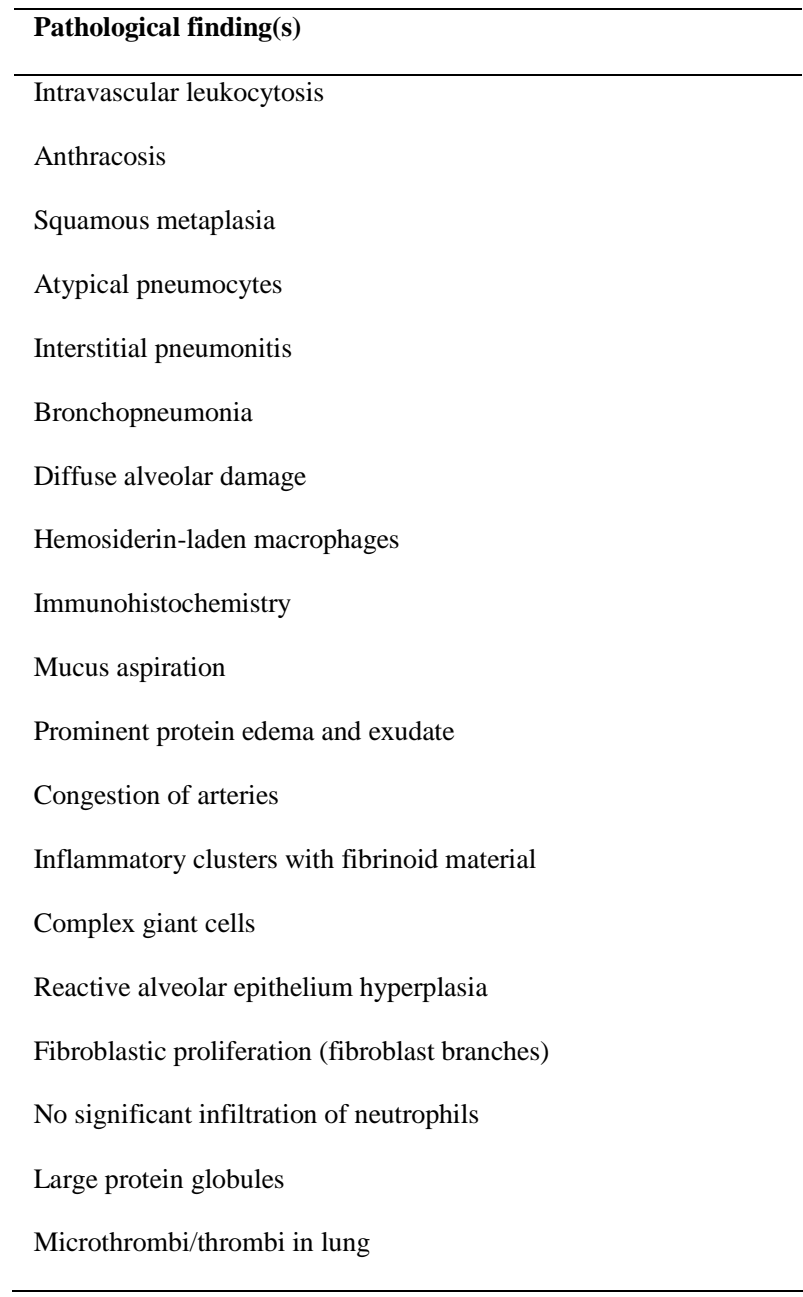

\section{Radiological findings}

Radiological findings in this disease are varied. These findings have been presented in Table 5. It is important to note that radiological diagnostic sensitivity is limited. Therefore, it is necessary to check with clinical signs and diagnosis of RNA virus (47).
Table 5. Radiological finding(s) in severe acute respiratory syndrome corona virus 2 (SARS-CoV-2)

\begin{tabular}{|c|c|c|}
\hline Radiological method & Finding & References \\
\hline Chest X-ray & $\begin{array}{l}\text { Lung consolidation } \\
\text { Ground glass densities } \\
\text { Bilateral lower lobe - } \\
\text { consolidations } \\
\text { Peripheral air space opacities } \\
\text { Diffuse air space disease } \\
\text { Pleural effusions } \\
\text { Lung cavitation } \\
\text { Pneumothorax } \\
\text { Diffuse chest walls subcutaneous- } \\
\text { emphysema } \\
\text { Pneumomediastinum }\end{array}$ & $(115-120)$ \\
\hline Chest Computed & Ground-glass opacities & $(107,118$ \\
\hline Tomography & $\begin{array}{l}\text { Consolidation } \\
\text { More than two lobes affected } \\
\text { Opacification distribution and- } \\
\text { pattern: Rounded morphology,- } \\
\text { Linear opacities, Crazy-paving - } \\
\text { pattern } \\
\text { Peripheral distribution } \\
\text { Reversed halo sign } \\
\text { Bilateral patchy shadowing } \\
\text { Normal (with no finding) }\end{array}$ & $121-123)$ \\
\hline Lung Ultrasound & $\begin{array}{l}\text { Bilateral involvement } \\
\text { Irregular pleura } \\
\text { Confluent B-lines } \\
\text { Small consolidations } \\
\text { Spared areas } \\
\text { Air bronchograms } \\
\text { Nontranslobar and translobar - } \\
\text { consolidation } \\
\text { Multifocal B-lines } \\
\text { Confluent B-lines } \\
\text { Pleural thickening/disruption }\end{array}$ & $(124-128)$ \\
\hline
\end{tabular}

\section{Prevention of SARS-CoV-2}

The best prevention for the general population at this period of time is to avoid being exposed to the virus (79). Some actions that may deduct amount of exposure of SARS-COV-2 infection include using face masks, 


\section{An update of coronavirus disease 2019...}

utilizing tissue or flexed arm when person coughs or sneezes, washing hands regularly with soap or disinfect hands with sanitizer consists of $60 \%$ alcohol at minimum, refusing close contact with suspicious or infected people and keeping a proper distance as much as possible to other people and refraining from touching eyes, nose, and mouth with unwashed hands (80).

\section{Vaccines of SARS-CoV-2}

Vaccines are biological drugs that are highly monitored and controlled. Unlike other drugs, which are administered on sick people, vaccines are administered on a huge number of healthy people, so the process of developing them takes a long time and should be strictly observed (81). There are several studies on developing vaccines for COVID-19 and each of them is at different stages. Some of them use messenger RNA methods and some of them use DNA, which is then translated and produces specific immunogenic proteins. Each of them uses different generic platforms, such as inactivated virus, purified recombinant viral proteins with or without adjuvant, replicating and non-replicating viral vectored antigens, antigen-encoding DNA or mRNA (82). Some of the vaccine designs are based on old methods and technologies that have been approved for other vaccines and some of them are built on completely new and novel technologies and have not been tested on large scales vaccinations (82).

Developing vaccines using the traditional ways takes a very long time almost 15 years. The vaccine developing process begins with designing and evaluating vaccine in animal models. Next, several years can take by other steps which are preclinical experiments for designing vaccine production and performing toxicology studies. Then, phase I clinical trials are the new drug on less than 100 people and this phase takes almost 2 years to see if the vaccine candidate is safe enough and has gained preliminary immunogenicity data. If the results are good, the vaccine candidate can move to phase II of clinical trials to test on a few hundred people and it takes another two years. In this phase appropriate dose and optimal vaccine regimen is determined. After this step, if the results are promising, the vaccine development process can move forward to phase III clinical trials in which the vaccine is tested on thousands of individuals to evaluate the effectiveness and safety of vaccine. This phase, which is a very costly process, takes another two years.
If the outcome is encouraging and meets the defined end points, an agency like United States Food and Drug Administration (FDA) or the European Medicine Agency approves the biological license application. This licensing process can take approximately two years.

Since the pandemic of SARS-COV-2 has started in December 2019, rapid action and development of vaccine is required. A considerable amount of time is saved by omitting some of the initial steps of exploratory vaccine design due to data from the preclinical development of vaccine candidates for SARS-COV and MERS-COV. In March 2020, the first clinical trial of a vaccine candidate for SARS-COV-2 was started. In this condition, trials are designed such that clinical phases are parallel and have overlaps. Phase I and II are started at the same time and are followed by rapid progression to phase III. Vaccine approval can be expedited through an emergency use authorization. In order to develop SARS-COV-2 vaccine, at least 50\% efficacy is required according to FDA guidance (83). In this pandemic, the COVID-19 vaccines should reach at least three goals of reducing severe infection, clinically symptomatic patients and the requirement of their hospitalization, being able to prevent the transmission of the disease between individuals and being capable of generate a strong neutralization response, which prevent the viral protein $\mathrm{S}$ from attaching to human cells by binding to it (81).

Currently, there are four main types of COVID-19 vaccines that are going to large scale clinical trials. In Table 6 clinically approved (passed Phase III) and commercialized vaccines are compared. Below is a description of how each type of vaccine works and induces our body to produce antibody against COVID19 antigens.

\section{Non-replicating viral vectors vaccines}

This type of vaccines is based on SARS-COV proteins expressing on the outer surface of some common viruses like adeno viruses, which are genetically modified. However, the immunity caused by these viruses are neutralized very soon because they are very common and most people come in touch with them. The common cold virus (adenovirus) is weakened and used as a viral vector, which contains the genome of surface $\mathrm{S}$ protein of SARS-CoV-2. After inoculating this vaccine, protein is produced and it can attack the corona virus since the immune system of the vaccinated person already has the antibodies specific to this protein. 
The recombinant adenovirus vector cannot cause a non-stop infection in the body, which received the vaccine because it does not reproduce and it also generates a strong single dose response. This type of vaccine uses type 5 of adenovirus as a vector that delivers the $\mathrm{S}$ protein of the coronavirus and teaches the body to detect the $\mathrm{S}$ protein corresponding to the coronavirus. This platform is the same as the Ebola virus vaccine $(81)$.

Table. 6. Latest vaccines for severe acute respiratory syndrome corona virus 2 (SARS-CoV-2) that passed phase III of clinical trials before July 2021

\begin{tabular}{|c|c|c|c|c|}
\hline Vaccine & $\begin{array}{c}\text { Pfizer/ } \\
\text { BioNTech }\end{array}$ & $\begin{array}{c}\text { Moderna/ } \\
\text { NIH }\end{array}$ & $\begin{array}{c}\text { Oxford/ } \\
\text { AstraZeneca }\end{array}$ & $\begin{array}{r}\text { Johnson \& } \\
\text { Johnson }\end{array}$ \\
\hline Type & mRNA & mRNA & $\begin{array}{l}\text { Adenoviral } \\
\text { vector }\end{array}$ & $\begin{array}{c}\text { Adenoviral } \\
\text { vector }\end{array}$ \\
\hline $\begin{array}{l}\text { Injection } \\
\text { time }\end{array}$ & 2 & 2 & 2 & 1 \\
\hline $\begin{array}{l}\text { Interval } \\
\text { (days) }\end{array}$ & $21-28$ & 28 (up to 42 ) & 8 to 12 weeks & NA \\
\hline $\begin{array}{l}\text { Dosage } \\
(\mathrm{mL})\end{array}$ & 0.3 & 0.5 & 0.5 & 0.5 \\
\hline Injection & Intra & Intra & Intra & Intra \\
\hline type & muscular & muscular & muscular & muscular \\
\hline Injection & Deltoid & Deltoid & Deltoid & Deltoid \\
\hline site & muscle & muscle & muscle & muscle \\
\hline $\begin{array}{c}\text { Effectivity } \\
(\%)\end{array}$ & 92 & 94.1 & 63.09 & 66.3 \\
\hline Reference & (129) & (87) & (130) & (131) \\
\hline
\end{tabular}

\section{Whole virus vaccines}

Live attenuated vaccines are the most potent immunogenic vaccines. They are made by diminishing the pathogenesis of SARS-CoV-2 with genetic engineering as same as BCG and most antiviral vaccines like polio with live strains, antimeasles, and anti-rubella. There is a risk of mutation that can cause these vaccines to be pathogenic again. This type of vaccines provides the vaccinated person with persistent protection as the natural post-infection immunogenicity but it can also cause severe post vaccination reactions. Inactivated viruses are made by inactivating the whole bacteria or virus by heat or formalization. This type has lower side effects but the post vaccine immunity is also less potent than the live attenuated ones (81).

\section{Protein-based vaccines}

Subunit vaccines with antigenic fragments are vaccines based on glycoprotein nanoparticles. This vaccine increases the immune response against the SARS-CoV2 spike proteins by elevating the levels of neutralizing antibodies using Matrix-M adjuvant. The production of antibodies is triggered by the antigen or antigenic fraction in the vaccine. It can have less side effects since some various components like cellular proteins or nucleic acids, which have no special effects on immunogenicity, are eliminated (81).

\section{Nucleic acid (RNA and DNA) vaccines}

Nucleic-acid vaccines are the fastest type of vaccines to develop because they do not require fermentation or culture. They are made by inserting mRNA or DNA into some cells and forcing them to make immunogenic viral proteins. Sequencing techniques and reverse genetics have a significant role to shorten the development time of a vaccine during the pandemic (84).

DNA vaccines like flu virus vaccine insert a foreign DNA into the cell's genome host and stimulates cellular immunity. Unlike most vaccines that address the humoral immunity, DNA vaccines stimulate cellular immunity. This type of vaccines has both advantages and disadvantages. Introduction of a live virus strain to the human body can be avoided by this type of vaccines but it also may increase oncogenic risks by inhibiting tumor suppressor genes or incorporating DNA into the host cell genome (85).

RNA vaccines are novel and have not been approved yet but they are candidates for COVID-19. This type of vaccines tries to stimulate the production of antibodies against the viral protein that is found on the surface of the virus spike. These antibodies can neutralize and block the cell infecting proteins in the respiratory tract (84).

Currently more than 50 different vaccine candidates are in trials all over the world. So far, two of them have achieved FDA authorization for public vaccination Pfizer-BioNTech and Moderna (86, 87). Other companies are also developing various types of COVID-19 vaccines (88). 


\section{Treatment of SARS-CoV-2}

We discuss treatment of this disease in two categories: supportive therapies and antiviral therapy.

\section{Supportive therapies}

Symptomatic and supportive therapy is the mainstay of treatment for SARS-CoV-2 cases (89). Supportive therapy includes different manners which are given to patients with SARS-CoV-2 infection for reaching different curative targets (Table 7). In addition, the plasma of recovering patients with SARS-CoV-2 may be useful for SARS-CoV-2 infection (90). New therapeutic approaches are developing including gene therapy (91), exosome therapy (92) and stem cell therapy (93) of COVID-19.

Table 7. Supportive therapy in severe acute respiratory syndrome corona virus 2 (SARS-CoV-2)

\begin{tabular}{|c|c|c|}
\hline Supportive therapy & Target & References \\
\hline Oxygen therapy & Control the level of $\mathrm{O}_{2}$ in body & (89) \\
\hline Maintenance of - & Prevent exacerbation of pulmonary & (89) \\
\hline electrolyte and water - & edema and decreased oxygen delivery & \\
\hline \multicolumn{3}{|l|}{ balance } \\
\hline Control of basal acid- & NA & $(89)$ \\
\hline \multicolumn{3}{|l|}{ levels } \\
\hline Zinc & May have antiviral activity & (132) \\
\hline \multirow[t]{3}{*}{ Azithromycin } & Effective in patients with severe & $(133,134)$ \\
\hline & respiratory tract infections suffering & \\
\hline & from viral infection & \\
\hline Vitamin C (ascorbic- & Enhancing the host immunity & $(133,135)$ \\
\hline \multicolumn{3}{|l|}{ acid) } \\
\hline \multirow[t]{4}{*}{ Corticosteroids } & Preventing an extended cytokine & (135) \\
\hline & response accelerate resolution of & \\
\hline & pulmonary and systemic inflammation & \\
\hline & in pneumonia & \\
\hline \multirow[t]{2}{*}{ NSAIDs } & May exhibit antiviral activity against & (135) \\
\hline & SARS-CoV & \\
\hline \multirow[t]{5}{*}{ Aspirin } & Inhibiting virus replication & (135) \\
\hline & Anti-platelet aggregation & \\
\hline & (anticoagulant action) & \\
\hline & Anti-inflammatory & \\
\hline & Anti-lung injury & \\
\hline
\end{tabular}

NA, not applicable; NSAIDs, Non-steroidal anti-inflammatory drugs; SARS-CoV, Severe Acute Respiratory Syndrome Corona Virus.

\section{Antiviral therapy}

At the present moment, numerous studies are ongoing to manufacture a vaccine against COVID-19. Though, developing vaccine is a long procedure, and the newly produced vaccine will need several safety assessments (94). Based on estimates, human society should wait at least one year to have an available vaccine against COVID-19 (95). Even after preparing an efficient vaccine, human trials will be a major challenge for scientists (Table 8). Now, COVID-19 is being cured with using broad-spectrum antiviral medicines counting remdesivir and Chinese herbal medicine $(96,97)$.

\section{Management of SARS-CoV-2}

At the present time that manufactured vaccines need long time to be available for all people around the world, it is important to manage patients with COVID-19. By knowing this fact, some notes should be considered in managing patients with COVID-19. Care ways of COVID-19 should be established at various levels of management including local, regional, and national levels for suspected or confirmed patients with COVID19 (98). Patients at the first point of contact within the health system should be screened based on case definitions and an assessment of symptoms, and then, suspected or confirmed cases enter into the pathway. Suspected cases should stay in the care pathway of COVID-19 until their lab tests show negative results. Isolating all suspected and confirmed cases in the shortest possible time, implementing local infection prevention and controlling manners are essential. Patients should be triaged by means of a standardized triage tool to evaluate the intensity of malady. Patient's values and priorities as well as local and national policy should be considered if accessible and proper judgments according to clinical situation should be utilized in order to steer handle decisions including admission to hospital and to the intensive care unit. For better managing of patients, some valuable data have been collected in Figure 5. 
Afshin Zare et al 31

Table 8. Antiviral drugs in severe acute respiratory syndrome corona virus 2 (SARS-CoV-2)

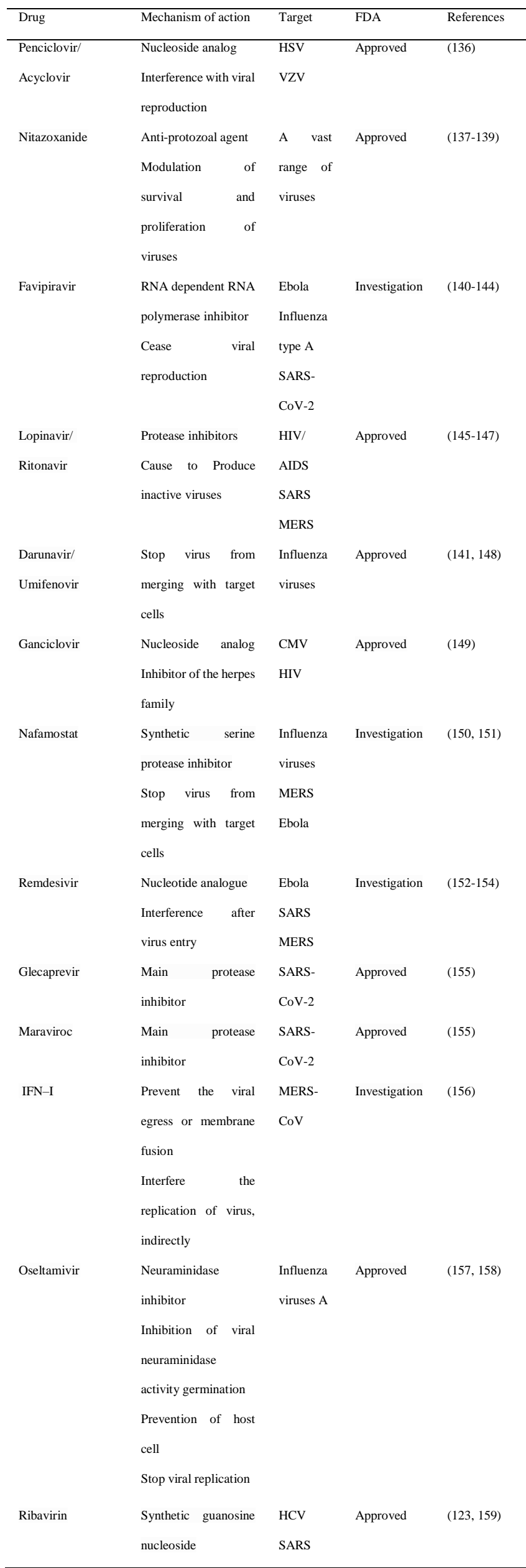

\begin{tabular}{lllll}
\hline & Disrupt producing & MERS & & \\
& viral mRNA & & \\
Chloroquine & Enhance the immune & Malaria Approved & & \\
& system & Autoimm & & \\
& Increase of autophagy & une & & \\
& suppressors & diseases & & \\
Hydroxy- & Enhancing & Malaria Approved \\
chloroquine & immune system & Autoimm & & \\
& Preventing the viral & une & & \\
& entry into the cells & diseases &
\end{tabular}

AIDS, Acquired immunodeficiency syndrome; CMV, Cytomegalovirus; HCV, Hepatitis $C$ virus; HIV, human immunodeficiency virus; HSV, Herpes simplex virus; MERS$\mathrm{CoV}$, Middle East respiratory syndrome coronavirus; MERS, Middle East respiratory syndrome; SARS, Severe acute respiratory syndrome; IFN-1, Type 1 interferon; VZV, Varicella zoster virus

Algorithm for a patient with suspcted COVID-19 in Emergency

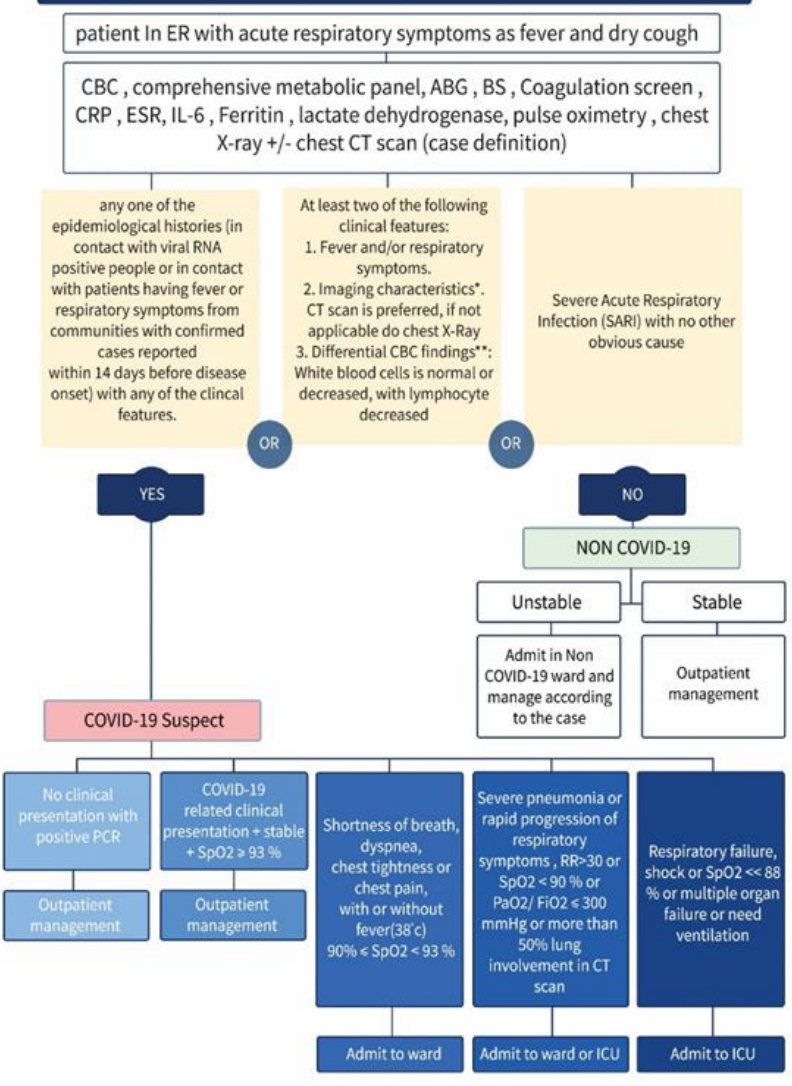

Figure 5. Management of patient with severe acute respiratory syndrome corona virus 2 (SARS-CoV-2) infection.

\section{Conclusions}

At present time, SARS-CoV-2 infection has become world-wide concern and causes many social and economic problems. This fact shows the importance of our approach to this infection. Considering this fact that vaccines for SARS-CoV-2 is not accessible for all people around the world because of limitations in producing, financial problems and political issues, best way to prevent from SARS-CoV-2 infection is minimum contact between people in each community. 
On the other hand, governments should prepare suitable facilities for scientists and researchers to know more about SARS-CoV-2 and its infection to manufacture proper, economical, accessible and beneficial treatments and vaccines for people all around the planet.

\section{Declarations}

\section{Acknowledgments}

Not applicable.

\section{Funding}

Not applicable.

\section{Conflicts of interest}

Author Mohammad Amin Behzadi was employed by the company Auro Vaccines LLC. The remaining authors declare that the research was conducted in the absence of any commercial or financial relationships that could be construed as a potential conflict of interest.

\section{Authors' Contributions}

A.Z., M.A.B., S.A., I.N., and A.T. conceived and designed the format of the manuscript. A.Z., S.F.S., A.M., N.P., Z.H., N.B., and A.K. drafted and edited the manuscript. M.A.B., S.A. and A.T. reviewed the manuscript. All authors contributed to the critical reading and discussion of the manuscript. All authors have read and agreed to the published version of the manuscript.

\section{References}

1. Zhu N, Zhang D, Wang W, Li X, Yang B, Song J, et al. A Novel Coronavirus from Patients with Pneumonia in China, 2019. N Engl J Med. 2020;382(8):727-33.

2. Jin Y, Yang H, Ji W, Wu W, Chen S, Zhang $\mathrm{W}$, et al. Virology, Epidemiology, Pathogenesis, and Control of COVID-19. Viruses. 2020;12(4):372.

3. Wang C, Horby PW, Hayden FG, Gao GF. A novel coronavirus outbreak of global health concern. Lancet. 2020;395(10223):470-3.

4. Beigel JH, Tomashek KM, Dodd LE, Mehta AK, Zingman BS, Kalil AC, et al. Remdesivir for the treatment of Covid-19preliminary report. N Engl J Med. 2020;383(10):992-3.

5. General Office of National Health Commission. General Office of National Administration of Traditional Chinese Medicine. Diagnostic and treatment protocol for Novel Coronavirus Pneumonia. 2020.
6. Cao B, Wang Y, Wen D, Liu W, Wang J, Fan G, et al. A Trial of Lopinavir-Ritonavir in Adults Hospitalized with Severe Covid-19. N Engl J Med. 2020;382(19):1787-99.

7. Cassady KA, Whitley RJ. Viral infections of the central nervous system. In: Richman DD, Whitley RJ, Hayden FJ, editors. Clinical Virology: Wiley; 2016.

8. Cascella M, Rajnik M, Cuomo A, Dulebohn SC, Di Napoli R. Features, evaluation and treatment coronavirus (COVID-19). StatPearls: StatPearls Publishing; 2020.

9. Elfiky AA, Mahdy SM, Elshemey WM. Quantitative structure-activity relationship and molecular docking revealed a potency of antihepatitis $\mathrm{C}$ virus drugs against human corona viruses. J Med Virol. 2017;89(6):1040-7.

10. Wu F, Zhao S, Yu B, Chen Y-M, Wang W, Song $\mathrm{Z}-\mathrm{G}$, et al. A new coronavirus associated with human respiratory disease in China. Nature. 2020;579(7798):265-9.

11. Cui J, Li F, Shi ZL. Origin and evolution of pathogenic coronaviruses. Nat Rev Microbiol. 2019; 17(3):181-92.

12. Lang Y, Li W, Li Z, Koerhuis D, Van Den Burg AC, Rozemuller E, et al. Coronavirus hemagglutininesterase and spike proteins coevolve for functional balance and optimal virion avidity. Proc Natl Acad Sci U S A. 2020;117(41):25759-70.

13. Tortorici MA, Veesler D. Structural insights into coronavirus entry. Adv Virus Res. 105: Elsevier; 2019. p. 93-116.

14. Angeletti S, Benvenuto D, Bianchi M, Giovanetti M, Pascarella S, Ciccozzi M. COVID2019: The role of the nsp2 and nsp3 in its pathogenesis. J Med Virol. 2020;92(6):584-8.

15. Hulswit RJG, Lang Y, Bakkers MJG, Li W, Li $\mathrm{Z}$, Schouten A, et al. Human coronaviruses OC43 and HKU1 bind to 9-O-acetylated sialic acids via a conserved receptor-binding site in spike protein domain A. Proc Natl Acad Sci U S A. 2019;116(7):2681-90.

16. Xia S, Zhu Y, Liu M, Lan Q, Xu W, Wu Y, et al. Fusion mechanism of $2019-\mathrm{nCoV}$ and fusion inhibitors targeting HR1 domain in spike protein. Cell Mol Immunol. 2020;17(7):765-7.

17. Tripp RA, Tompkins SM. Roles of host gene and non-coding RNA expression in virus infection: Springer International Publishing; 2018.

18. Sawicki S, Sawicki D. Coronavirus transcription: a perspective. Coronavirus replication and reverse genetics: Springer; 2005. p. 31-55.

19. Hussain S, Pan J, Chen Y, Yang Y, Xu J, Peng $\mathrm{Y}$, et al. Identification of novel subgenomic RNAs and noncanonical transcription initiation signals of severe acute respiratory syndrome coronavirus. J Virol. 2005;79(9):5288-95. 
20. Perrier A, Bonnin A, Desmarets L, Danneels A, Goffard A, Rouille Y, et al. The Cterminal domain of the MERS coronavirus $M$ protein contains a trans-Golgi network localization signal. J Biol Chem. 2019;294(39):14406-21.

21. Huang C, Wang Y, Li X, Ren L, Zhao J, $\mathrm{Hu} \mathrm{Y}$, et al. Clinical features of patients infected with 2019 novel coronavirus in Wuhan, China. Lancet. 2020;395(10223):497-506.

22. Wen-Bin Y, Li Z, Richard TC. Decoding the evolution and transmissions of the novel pneumonia coronavirus (SARS-CoV-2/HCoV-19) using whole genomic data. Zool Res. 2020;41(3):247-57.

23. Woo PC, Lau SK, Lam CS, Lau CC, Tsang AK, Lau JH, et al. Discovery of seven novel Mammalian and avian coronaviruses in the genus deltacoronavirus supports bat coronaviruses as the gene source of alphacoronavirus and betacoronavirus and avian coronaviruses as the gene source of gammacoronavirus and deltacoronavirus. J Virol. 2012;86(7):3995-4008.

24. Nadeem MS, Zamzami MA, Choudhry H, Murtaza BN, Kazmi I, Ahmad H, et al. Origin, Potential Therapeutic Targets and Treatment for Coronavirus Disease (COVID-19). Pathogens. 2020;9(4):307.

25. Zhang H, Penninger JM, Li Y, Zhong N, Slutsky AS. Angiotensin-converting enzyme 2 (ACE2) as a SARS-CoV-2 receptor: molecular mechanisms and potential therapeutic target. Intensive Care Med. 2020;46(4):586-90.

26. Hu B, Zeng L-P, Yang X-L, Ge X-Y, Zhang W, Li B, et al. Discovery of a rich gene pool of bat SARS-related coronaviruses provides new insights into the origin of SARS coronavirus. PLoS Pathog. 2017;13(11):e1006698.

27. Wan Y, Shang J, Graham R, Baric RS, Li F. Receptor Recognition by the Novel Coronavirus from Wuhan: an Analysis Based on Decade-Long Structural Studies of SARS Coronavirus. J Virol. 2020;94(7):e00127-20.

28. Zhang L, Shen FM, Chen F, Lin Z. Origin and Evolution of the 2019 Novel Coronavirus. Clin Infect Dis. 2020;71(15):882-3.

29. Zhao J, Cui W, Tian B-p. The potential intermediate hosts for SARS-CoV-2. Front Microbiol. 2020;11:2400.

30. Andersen KG, Rambaut A, Lipkin WI, Holmes EC, Garry RF. The proximal origin of SARS-CoV-2. Nat Med. 2020;26(4):450-2.

31. Zhou P, Yang X-L, Wang X-G, Hu B, Zhang L, Zhang W, et al. A pneumonia outbreak associated with a new coronavirus of probable bat origin. Nature. 2020;579(7798):270-3.
32. Li X, Zai J, Zhao Q, Nie Q, Li Y, Foley BT, et al. Evolutionary history, potential intermediate animal host, and cross-species analyses of SARSCoV-2. J Med Virol. 2020;92(6):602-11.

33. Li Q, Guan X, Wu P, Wang X, Zhou L, Tong Y, et al. Early Transmission Dynamics in Wuhan, China, of Novel Coronavirus-Infected Pneumonia. N Engl J Med. 2020;382(13):1199-207.

34. Duffy S. Why are RNA virus mutation rates so damn high? PLoS Biol. 2018;16(8):e3000003.

35. Domingo E. Quasispecies theory in virology. J Virol. 2002;76(1):463-5.

36. Pachetti M, Marini B, Benedetti F, Giudici F, Mauro E, Storici P, et al. Emerging SARS-CoV-2 mutation hot spots include a novel RNA-dependentRNA polymerase variant. J Transl Med. 2020;18(1):179.

37. Hou YJ, Chiba S, Halfmann P, Ehre C, Kuroda M, Dinnon KH, et al. SARS-CoV-2 D614G variant exhibits efficient replication ex vivo and transmission in vivo. Science. 2020;370(6523):1464-8.

38. Daniloski Z, Jordan TX, Ilmain JK, Guo X, Bhabha G, tenOever BR, et al. The Spike D614G mutation increases SARS-CoV-2 infection of multiple human cell types. Elife. 2021;10:e65365.

39. Sanyaolu A, Okorie C, Marinkovic A, Haider N, Abbasi AF, Jaferi U, et al. The emerging SARS-CoV2 variants of concern. Ther Adv Infect Dis. 2021;8:20499361211024372.

40. Leung K, Shum MH, Leung GM, Lam TT, Wu JT. Early transmissibility assessment of the N501Y mutant strains of SARS-CoV-2 in the United Kingdom, October to November 2020. Euro Surveill. 2021;26(1):2002106.

41. Davies NG, Abbott S, Barnard RC, Jarvis CI, Kucharski AJ, Munday JD, et al. Estimated transmissibility and impact of SARS-CoV-2 lineage B.1.1.7 in England. Science. 2021;372(6538):eabg3055.

42. World Health Organization. SARS-CoV-2 Variants 2020 [Available from: https://www.who.int/csr/don/31-december-2020sars-cov2-variants/en/.

43. Starr TN, Greaney AJ, Hilton SK, Ellis D, Crawford KH, Dingens AS, et al. Deep mutational scanning of SARS-CoV-2 receptor binding domain reveals constraints on folding and ACE2 binding. Cell. 2020;182(5):1295-310. e20.

44. Lan J, Ge J, Yu J, Shan S, Zhou H, Fan S, et al. Structure of the SARS-CoV-2 spike receptor-binding domain bound to the ACE2 receptor. Nature. 2020;581(7807):215-20.

45. Tegally H, Wilkinson E, Lessells RJ, Giandhari J, Pillay S, Msomi N, et al. Sixteen novel lineages of SARS-CoV-2 in South Africa. Nat Med. 2021;27(3):440-6. 
46. Zhang W, Du RH, Li B, Zheng XS, Yang $\mathrm{XL}, \mathrm{Hu} \mathrm{B}$, et al. Molecular and serological investigation of 2019-nCoV infected patients: implication of multiple shedding routes. Emerg Microbes Infect. 2020;9(1):386-9.

47. Guo Y-R, Cao Q-D, Hong Z-S, Tan Y-Y, Chen S-D, Jin H-J, et al. The origin, transmission and clinical therapies on coronavirus disease 2019 (COVID-19) outbreak-an update on the status. Mil Med Res. 2020;7(1):11.

48. Bordbar A, Kashaki M, Rezaei F, Jafari R. Vertical transmission of COVID-19 in a 1-day-old neonate. Travel Med Infect Dis. 2020;38:101879.

49. Principi N, Bosis S, Esposito S. Effects of coronavirus infections in children. Emerg Infect Dis. 2010;16(2):183-8.

50. Zumla A, Hui DS, Perlman S. Middle East respiratory syndrome. Lancet. 2015;386(9997):995-1007.

51. Chen H, Guo J, Wang C, Luo F, Yu X, Zhang $\mathrm{W}$, et al. Clinical characteristics and intrauterine vertical transmission potential of COVID-19 infection in nine pregnant women: a retrospective review of medical records. Lancet. 2020;395(10226):809-15.

52. Ran L, Chen X, Wang Y, Wu W, Zhang L, Tan X. Risk factors of healthcare workers with corona virus disease 2019: a retrospective cohort study in a designated hospital of Wuhan in China. Clin Infect Dis. 2020.

53. Hoffmann $M, \quad$ Kleine-Weber $H$, Schroeder S, Krüger N, Herrler T, Erichsen S, et al. SARS-CoV-2 cell entry depends on ACE2 and TMPRSS 2 and is blocked by a clinically proven protease inhibitor. Cell. 2020;181(2):271-80.

54. Jia HP, Look DC, Shi L, Hickey M, Pewe L, Netland J, et al. ACE2 receptor expression and severe acute respiratory syndrome coronavirus infection depend on differentiation of human airway epithelia. J Virol. 2005;79(23):14614-21.

55. $\mathrm{Lu}$ Q, Shi Y. Coronavirus disease (COVID-19) and neonate: What neonatologist need to know. J Med Virol. 2020;92(6):564-7.

56. Qin J, You C, Lin Q, Hu T, Yu S, Zhou $\mathrm{XH}$. Estimation of incubation period distribution of COVID-19 using disease onset forward time: A novel cross-sectional and forward follow-up study. Sci Adv. 2020;6(33):eabc1202.

57. Heymann DL, Shindo N. COVID-19: what is next for public health? Lancet. 2020;395(10224):542-5.

58. Yan J, Guo J, Fan C, Juan J, Yu X, Li J, et al. Coronavirus disease 2019 (COVID-19) in pregnant women: A report based on 116 cases. Am J Obstet Gynecol. 2020;223:111.e1-.

59. Dashraath P, Wong JLJ, Lim MXK, Lim LM, Li S, Biswas A, et al. Coronavirus disease 2019 (COVID-19) pandemic and pregnancy. Am J Obstet Gynecol. 2020;222(6):521-31.

Vol.4 No.1 Spring \& Summer 2021
60. Ryan GA, Purandare NC, McAuliffe FM, Hod M, Purandare CN. Clinical update on COVID-19 in pregnancy: A review article. J Obstet Gynaecol Res. 2020;46(8):1235-45.

61. Yu N, Li W, Kang Q, Xiong Z, Wang S, Lin X, et al. Clinical features and obstetric and neonatal outcomes of pregnant patients with COVID-19 in Wuhan, China: a retrospective, single-centre, descriptive study. Lancet Infect Dis. 2020;20(5):55964.

62. Baud D, Giannoni E, Pomar L, Qi X, NielsenSaines K, Musso D, et al. COVID-19 in pregnant women-Authors' reply. Lancet Infect Dis. 2020;20(6):654.

63. Wastnedge EAN, Reynolds RM, van Boeckel SR, Stock SJ, Denison FC, Maybin JA, et al. Pregnancy and COVID-19. Physiol Rev. 2021;101(1):303-18.

64. Zhu H, Wang L, Fang C, Peng S, Zhang L, Chang $\mathrm{G}$, et al. Clinical analysis of 10 neonates born to mothers with 2019-nCoV pneumonia. Transl Pediatr. 2020;9(1):51-60.

65. De Bernardo G, Giordano M, Zollo G, Chiatto F, Sordino D, De Santis R, et al. The clinical course of SARS-CoV-2 positive neonates. J Perinatol. 2020;40(10):1462-9.

66. Silasi M, Cardenas I, Kwon JY, Racicot K, Aldo $\mathrm{P}$, Mor G. Viral infections during pregnancy. Am J Reprod Immunol. 2015;73(3):199-213.

67. Chen L, Li Q, Zheng D, Jiang H, Wei Y, Zou L, et al. Clinical characteristics of pregnant women with Covid-19 in Wuhan, China. N Engl J Med. 2020;382(25):e100.

68. Keskin-Arslan E, Kaplan YC, Koren G. Use of azithromycin during pregnancy and breastfeeding: A coronavirus pan-demic (COVID-19) update. Motherisk Int J. 2020;1:12.

69. Burwick RM, Yawetz S, Stephenson KE, Collier A-RY, Sen P, Blackburn BG, et al. Compassionate use of remdesivir in pregnant women with severe coronavirus disease 2019. Clinical Infectious Diseases: An Official Publication of the Infectious Diseases Society of America. 2020.

70. Saad AF, Chappell L, Saade GR, Pacheco LD. Corticosteroids in the Management of Pregnant Patients With Coronavirus Disease (COVID-19). Obstet Gynecol. 2020;136(4):823-6.

71. Di Renzo GC, Giardina I. Coronavirus disease 2019 in pregnancy: consider thromboembolic disorders and thromboprophylaxis. Am J Obstet Gynecol. 2020;223(1):135.

72. Karimian M, Mansouri F, Borji M, Tarjoman A, Mahdikhani S, Soltany B, et al. Prevention, diagnosis, and treatment of covid-19 in infants and children: a systematic review study of performed protocols. Arch Clin Infect Dis. 2020;15(6): e103180. 
73.

Saeedi M, Sangsari R, Mirnia K. COVID-

19 in Neonates: A Review. Iran J Pediatr. 2021;31(1):e104423.

74. Zare-Zardini H, Soltaninejad H, Ferdosian F, Hamidieh AA, Memarpoor-Yazdi M. Coronavirus disease 2019 (COVID-19) in children: prevalence, diagnosis, clinical symptoms, and treatment. Int J Gen Med. 2020;13:477-82.

75. Dong Y, Mo X, Hu Y, Qi X, Jiang F, Jiang $\mathrm{Z}$, et al. Epidemiology of COVID-19 among children in China. Pediatrics. 2020;145(6):e20200702.

76. Karimi A, Rafiei Tabatabaei S, Rajabnejad M, Pourmoghaddas Z, Rahimi H, Armin $\mathrm{S}$, et al. An algorithmic approach to diagnosis and treatment of coronavirus disease 2019 (COVID-19) in children: Iranian expert's consensus statement. Arch Clin Infect Dis. 2020;8(2): e102400.

77. Luo W, Yu H, Gou J, Li X, Sun Y, Li J, et al. Clinical pathology of critical patient with novel coronavirus pneumonia (COVID-19). Preprints. 2020;2020:2020020407.

78. Menter T, Haslbauer JD, Nienhold R, Savic S, Hopfer H, Deigendesch $N$, et al. Postmortem examination of COVID-19 patients reveals diffuse alveolar damage with severe capillary congestion and variegated findings in lungs and other organs suggesting vascular dysfunction. Histopathology. 2020;77(2):198-209.

79. Ou F, Wu H, Yang Y, Tan W, Zhang J, $\mathrm{Gu}$ J. Countermeasures for rapid spread of new coronavirus pneumonia in Wuhan. Chinese General Practicing Nursing. 2020.

80. Calisher C, Carroll D, Colwell R, Corley RB, Daszak P, Drosten C, et al. Statement in support of the scientists, public health professionals, and medical professionals of China combatting COVID19. Lancet. 2020;395(10226):e42-e3.

81. Calina D, Sarkar C, Arsene AL, Salehi B, Docea AO, Mondal M, et al. Recent advances, approaches and challenges in targeting pathways for potential COVID-19 vaccines development. Immunol Res. 2020;68(6):315-24.

82. Locht C. Vaccines against COVID-19. Anaesth Crit Care Pain Med. 2020;39(6):703-5.

83. Krammer F. SARS-CoV-2 vaccines in development. Nature. 2020;586(7830):516-27.

84. de Queiroz N, Marinho FV, Chagas MA,

Leite LCC, Homan EJ, de Magalhaes MTQ, et al. Vaccines for COVID-19: perspectives from nucleic acid vaccines to BCG as delivery vector system. Microbes Infect. 2020;22(10):515-24.

85. Silveira MM, Moreira G, Mendonca M. DNA vaccines against COVID-19: Perspectives and challenges. Life Sci. 2021;267:118919.

86. Tanne JH. Covid-19: FDA panel votes to authorise Pfizer BioNTech vaccine. BMJ. 2020;371:m4799.
87. Oliver SE. The advisory committee on immunization practices' interim recommendation for use of moderna COVID-19 vaccine-United States, December 2020. MMWR Morb Mortal Wkly Rep. 2021;69(5152):1653-6.

88. Venkadapathi J, Govindarajan VK, Sekaran S, Venkatapathy S. A minireview of the promising drugs and vaccines in pipeline for the treatment of COVID-19 and current update on clinical trials. Front Mol Biosci. 2021;8:637378.

89. Wang L, Shi Y, Xiao T, Fu J, Feng X, Mu D, et al. Chinese expert consensus on the perinatal and neonatal management for the prevention and control of the 2019 novel coronavirus infection (First edition). Ann Transl Med. 2020;8(3):47.

90. Mair-Jenkins J, Saavedra-Campos M, Baillie JK, Cleary P, Khaw FM, Lim WS, et al. The effectiveness of convalescent plasma and hyperimmune immunoglobulin for the treatment of severe acute respiratory infections of viral etiology: a systematic review and exploratory meta-analysis. J Infect Dis. 2015;211(1):80-90.

91. Afshar A, Zare M, Farrar Z, Hashemi A, Khoradmehr A, Habibi H, et al. COVID-19 hypothesis: Exosomes of mesenchymal stem cells as nano-cargos for anti-SARS-CoV-2 asRNAs. Mod Med Lab J. 2021;4(1):11-18.

92. Hassanpour M, Rezaie J, Nouri M, Panahi Y. The role of extracellular vesicles in COVID-19 virus infection. Infect Genet Evol. 2020;85:104422.

93. Li Z, Niu S, Guo B, Gao T, Wang L, Wang Y, et al. Stem cell therapy for COVID-19, ARDS and pulmonary fibrosis. Cell Prolif. 2020;53(12):e12939. 94. Chen D, Xu W, Lei Z, Huang Z, Liu J, Gao Z, et al. Recurrence of positive SARS-CoV-2 RNA in COVID-19: A case report. Int $J$ Infect Dis. 2020;93:297-9.

95. Jiang F, Deng L, Zhang L, Cai Y, Cheung CW, Xia Z. Review of the clinical characteristics of coronavirus disease 2019 (COVID-19). J Gen Intern Med. 2020;35(5):1545-9.

96. Li G, De Clercq E. Therapeutic options for the 2019 novel coronavirus (2019-nCoV). Nat Rev Drug Discov. 2020;19(3):149-50.

97. Luo H, Tang Q-1, Shang Y-x, Liang S-b, Yang $\mathrm{M}$, Robinson N, et al. Can Chinese medicine be used for prevention of corona virus disease 2019 (COVID19)? A review of historical classics, research evidence and current prevention programs. Chin $\mathbf{J}$ Integr Med. 2020:1-8.

98. Samieefar N, Boroujeni RY, Jamee M, Lotfi M, Golabchi MR, Afshar A, et al. Country quarantine during COVID-19: critical or not? Disaster Med Public Health Prep. 2020:1-2. 
99. Lei J, Kusov Y, Hilgenfeld R. Nsp3 of coronaviruses: Structures and functions of a large multi-domain protein. Antiviral Res. 2018;149:5874.

100. Song W, Gui M, Wang X, Xiang Y. CryoEM structure of the SARS coronavirus spike glycoprotein in complex with its host cell receptor ACE2. PLoS Pathog. 2018;14(8):e1007236.

101. de Abajo FJ, Rodríguez-Martín S, Lerma V, Mejía-Abril G, Aguilar M, García-Luque A, et al. Use of renin-angiotensin-aldosterone system inhibitors and risk of COVID-19 requiring admission to hospital: a case-population study. Lancet. 2020;395(10238):1705-14.

102. Al-Omari A, Alhuqbani WN, Zaidi ARZ, Al-Subaie MF, AlHindi AM, Abogosh AK, et al. Clinical characteristics of non-intensive care unit COVID-19 patients in Saudi Arabia: a descriptive cross-sectional study. J Infect Public Health. 2020;13(11):1639-44.

103. Miller J, Cantor A, Zachariah P, Ahn D, Martinez M, Margolis KG. Gastrointestinal symptoms as a major presentation component of a novel multisystem inflammatory syndrome in children that is related to coronavirus disease 2019: a single center experience of 44 cases. Gastroenterology. 2020;159(4):1571-4. e2.

104. Graham EL, Clark JR, Orban ZS, Lim PH, Szymanski AL, Taylor C, et al. Persistent neurologic symptoms and cognitive dysfunction in non-hospitalized Covid-19 "long haulers". Ann Clin Transl Neurol. 2021;8(5):1073-85.

105. Inciardi RM, Lupi L, Zaccone G, Italia L, Raffo M, Tomasoni D, et al. Cardiac involvement in a patient with coronavirus disease 2019 (COVID19). JAMA cardiology. 2020;5(7):819-24.

106. Paradowska-Stolarz AM. Oral manifestations of COVID-19: Brief review. Dent Med Probl. 2021;58(1):123-6.

107. Guan WJ, Ni ZY, Hu Y, Liang WH, Ou $\mathrm{CQ}, \mathrm{He} \mathrm{JX}$, et al. Clinical Characteristics of Coronavirus Disease 2019 in China. N Engl J Med. 2020;382(18):1708-20.

108. Liu K, Fang YY, Deng Y, Liu W, Wang MF, Ma JP, et al. Clinical characteristics of novel coronavirus cases in tertiary hospitals in Hubei Province. Chin Med J (Engl). 2020;133(9):1025-31. 109. Jin R. Recommendation for the diagnosis and treatment of novel coronavirus infection in children in Hubei (Trial version 1). Zhongguo Dang Dai Er Ke Za Zhi. 2020;22(2):96-9.

110. Martines RB, Ritter JM, Matkovic E, Gary J, Bollweg BC, Bullock H, et al. Pathology and pathogenesis of SARS-CoV-2 associated with fatal coronavirus disease, United States. Emerg Infect Dis. 2020;26(9):2005-15.
111. Tian S, Hu W, Niu L, Liu H, Xu H, Xiao SY. Pulmonary pathology of early-phase 2019 novel coronavirus (COVID-19) pneumonia in two patients with lung cancer. J Thorac Oncol. 2020;15(5):700-4. 112. Carsana L, Sonzogni A, Nasr A, Rossi RS, Pellegrinelli A, Zerbi P, et al. Pulmonary postmortem findings in a series of COVID-19 cases from northern Italy: a two-centre descriptive study. Lancet Infect Dis. 2020;20(10):1135-40.

113. Schaller T, Hirschbuhl K, Burkhardt K, Braun G, Trepel M, Markl B, et al. Postmortem examination of patients with COVID-19. JAMA. 2020;323(24):2518-20.

114. Remmelink M, De Mendonca R, D'Haene N, De Clercq S, Verocq C, Lebrun L, et al. Unspecific postmortem findings despite multiorgan viral spread in COVID-19 patients. Crit Care. 2020;24(1):495.

115. Zhou S, Wang Y, Zhu T, Xia L. CT features of coronavirus disease 2019 (COVID-19) pneumonia in 62 patients in Wuhan, China. AJR Am J Roentgenol. 2020;214(6):1287-94.

116. Littrup PJ, Freeman-Gibb L, Andea A, White M, Amerikia KC, Bouwman D, et al. Cryotherapy for breast fibroadenomas. Radiology. 2005;234(1):6372.

117. Wong HYF, Lam HYS, Fong AH, Leung ST, Chin TW, Lo CSY, et al. Frequency and distribution of chest radiographic findings in patients positive for COVID-19. Radiology. 2020;296(2):E72-E8.

118. Bernheim A, Mei X, Huang M, Yang Y, Fayad $\mathrm{ZA}$, Zhang N, et al. Chest $\mathrm{CT}$ findings in coronavirus disease-19 (COVID-19): relationship to duration of infection. Radiology. 2020;295(3):200463.

119. Gozansky EK, Moore WH. SARS-CoV-2 from the trenches: A perspective from New York city. AJR Am J Roentgenol. 2020;215(1):27-8.

120. Sun R, Liu H, Wang X. Mediastinal emphysema, giant bulla, and pneumothorax developed during the course of COVID-19 pneumonia. Korean J Radiol. 2020;21(5):541-4.

121. Lei J, Li J, Li X, Qi X. CT imaging of the 2019 novel coronavirus (2019-nCoV) pneumonia. Radiology. 2020;295(1):18.

122. Kong W, Agarwal PP. Chest imaging appearance of COVID-19 infectionp. Radiol Cardiothorac Imaging. 2020;2(1):e200028.

123. Chung M, Bernheim A, Mei X, Zhang N, Huang M, Zeng X, et al. CT imaging features of 2019 novel coronavirus (2019-nCoV). Radiology. 2020;295(1):202-7.

124. Buonsenso D, Piano A, Raffaelli F, Bonadia N, de Gaetano Donati K, Franceschi F. Point-of-Care Lung Ultrasound findings in novel coronavirus disease-19 pnemoniae: a case report and potential applications during COVID-19 outbreak. Eur Rev Med Pharmacol Sci. 2020;24(5):2776-80. 
125. Moro F, Buonsenso D, Moruzzi M, Inchingolo R, Smargiassi A, Demi L, et al. How to perform lung ultrasound in pregnant women with suspected COVID-19. Ultrasound Obstet Gynecol. 2020;55(5):593-8.

126. Peng Q-Y, Wang X-T, Zhang L-N. Findings of lung ultrasonography of novel corona virus pneumonia during the 2019-2020 epidemic. Intensive Care Med. 2020;46(5):849-50.

127. Thomas A, Haljan G, Mitra A. Lung ultrasound findings in a 64-year-old woman with COVID-19. CMAJ. 2020;192(15):E399.

128. Vetrugno L, Bove T, Orso D, Barbariol F, Bassi F, Boero E, et al. Our Italian experience using lung ultrasound for identification, grading and serial follow-up of severity of lung involvement for management of patients with COVID-19. Echocardiography. 2020;37(4):625-7.

129. Oliver SE, Gargano JW, Marin M, Wallace M, Curran KG, Chamberland M, et al. The advisory committee on immunization practices' interim recommendation for use of PfizerBioNTech COVID-19 vaccine-United States, December 2020. MMWR Morb Mortal Wkly Rep. 2020;69(50):1922-4.

130. Knoll MD, Wonodi C. OxfordAstraZeneca COVID-19 vaccine efficacy. Lancet. 2021;397(10269):72-4.

131. Oliver SE, Gargano JW, Scobie H, Wallace M, Hadler SC, Leung J, et al. The advisory committee on immunization practices' interim recommendation for use of Janssen COVID-19 vaccine-United States, February 2021. MMWR Morb Mortal Wkly Rep. 2021;70(9):329-32.

132. Sarma P, Prajapat M, Avti P, Kaur H, Kumar S, Medhi B. Therapeutic options for the treatment of 2019-novel coronavirus: An evidencebased approach. Indian J Pharmacol. 2020;52(1):15 .

133. Wu R, Wang L, Kuo HD, Shannar A, Peter R, Chou PJ, et al. An Update on Current Therapeutic Drugs Treating COVID-19. Curr Pharmacol Rep. 2020:1-15.

134. Asai A, Konno M, Ozaki M, Otsuka C, Vecchione A, Arai T, et al. COVID-19 drug discovery using intensive approaches. Int J Mol Sci. 2020;21(8):2839.

135. Rudrapal M, Khairnar SJ, Borse LB, Jadhav AG. Coronavirus disease-2019 (COVID19): an updated review. Drug Res (Stuttg). 2020;70(9):389-400.

136. Shiraki K. Antiviral drugs against alphaherpesvirus. Human Herpesviruses: Springer; 2018. p. 103-22.

137. Cao J, Forrest JC, Zhang X. A screen of the NIH Clinical Collection small molecule library identifies potential anti-coronavirus drugs. Antiviral Res. 2015;114:1-10.
138. Rossignol JF. Nitazoxanide: a first-in-class broad-spectrum antiviral agent. Antiviral Res. 2014;110:94-103.

139. Rossignol JF. Nitazoxanide, a new drug candidate for the treatment of Middle East respiratory syndrome coronavirus. J Infect Public Health. 2016;9(3):227-30.

140. Cardile AP, Warren TK, Martins KA, Reisler RB, Bavari S. Will there be a cure for Ebola? Annu Rev Pharmacol Toxicoll. 2017;57:329-48.

141. Dong L, Hu S, Gao J. Discovering drugs to treat coronavirus disease 2019 (COVID-19). Drug Discov Ther. 2020;14(1):58-60.

142. Furuta Y, Gowen BB, Takahashi K, Shiraki K, Smee DF, Barnard DL. Favipiravir (T-705), a novel viral RNA polymerase inhibitor. Antiviral Res. 2013;100(2):446-54.

143. Goldhill DH, Te Velthuis AJW, Fletcher RA, Langat $\mathrm{P}$, Zambon M, Lackenby A, et al. The mechanism of resistance to favipiravir in influenza. Proc Natl Acad Sci U S A. 2018;115(45):11613-8.

144. Nagata T, Lefor AK, Hasegawa M, Ishii M. Favipiravir: a new medication for the Ebola virus disease pandemic. Disaster Med Public Health Prep. 2015;9(1):79-81.

145. Arabi YM, Asiri AY, Assiri AM, Aziz Jokhdar HA, Alothman A, Balkhy HH, et al. Treatment of Middle East respiratory syndrome with a combination of lopinavir/ritonavir and interferon-beta $1 \mathrm{~b}$ (MIRACLE trial): statistical analysis plan for a recursive two-stage group sequential randomized controlled trial. Trials. 2020;21(1):8.

146. Chu CM, Cheng VC, Hung IF, Wong MM, Chan $\mathrm{KH}$, Chan KS, et al. Role of lopinavir/ritonavir in the treatment of SARS: initial virological and clinical findings. Thorax. 2004;59(3):252-6.

147. Cvetkovic RS, Goa KL. Lopinavir/ritonavir: a review of its use in the management of HIV infection. Drugs. 2003;63(8):769-802.

148. Kadam RU, Wilson IA. Structural basis of influenza virus fusion inhibition by the antiviral drug Arbidol. Proc Natl Acad Sci U S A. 2017;114(2):20614.

149. Al-Badr AA, Ajarim TD. Ganciclovir. Profiles Drug Subst Excip Relat Methodol. 2018;43:1-208.

150. Hsieh HP, Hsu JT. Strategies of development of antiviral agents directed against influenza virus replication. Curr Pharm Des. 2007;13(34):3531-42.

151. Nishimura H, Yamaya M. A synthetic serine protease inhibitor, Nafamostat Mesilate, is a drug potentially applicable to the treatment of ebola virus disease. Tohoku J Exp Medc. 2015;237(1):45-50.

152. Agostini ML, Andres EL, Sims AC, Graham RL, Sheahan TP, Lu X, et al. Coronavirus susceptibility to the antiviral remdesivir (GS-5734) is mediated by the viral polymerase and the proofreading exoribonuclease. mBio. 2018;9(2):e00221-e002218. 
153. Lo MK, Feldmann F, Gary JM, Jordan R, Bannister R, Cronin J, et al. Remdesivir (GS-5734) protects African green monkeys from Nipah virus challenge. Sci Transl Med. 2019;11(494):eaau9242. 154. Tchesnokov EP, Feng JY, Porter DP, Gotte M. Mechanism of inhibition of Ebola virus RNA-dependent RNA polymerase by remdesivir. Viruses. 2019;11(4):326.

155. Shamsi A, Mohammad T, Anwar S, AlAjmi MF, Hussain A, Rehman MT, et al. Glecaprevir and Maraviroc are high-affinity inhibitors of SARS-CoV-2 main protease: possible implication in COVID-19 therapy. Biosci Rep. 2020;40(6).

156. Sallard E, Lescure FX, Yazdanpanah Y, Mentre F, Peiffer-Smadja N. Type 1 interferons as a potential treatment against COVID-19. Antiviral Res. 2020;178:104791.

157. Jefferson T, Jones M, Doshi P, Spencer EA, Onakpoya I, Heneghan CJ. Oseltamivir for influenza in adults and children: systematic review of clinical study reports and summary of regulatory comments. BMJ. 2014;348:g2545.

158. McQuade B, Blair M. Influenza treatment with oseltamivir outside of labeled recommendations. Am J Health Syst Pharm. 2015;72(2):112-6.

159. Arabi YM, Shalhoub S, Mandourah Y, Al-Hameed F, Al-Omari A, Al Qasim E, et al. Ribavirin and interferon therapy for critically IIl patients with Middle East respiratory syndrome: A multicenter observational study. Clin Infect Dis. 2020;70(9):1837-44.

160. Golden EB, Cho HY, Hofman FM, Louie SG, Schonthal AH, Chen TC. Quinoline-based antimalarial drugs: a novel class of autophagy inhibitors. Neurosurg Focus. 2015;38(3):E12.

161. Savarino A, Boelaert JR, Cassone A, Majori G, Cauda R. Effects of chloroquine on viral infections: an old drug against today's diseases? Lancet Infect Dis. 2003;3(11):722-7.

162. Vincent MJ, Bergeron E, Benjannet S, Erickson BR, Rollin PE, Ksiazek TG, et al. Chloroquine is a potent inhibitor of SARS coronavirus infection and spread. Virol $\mathrm{J}$. 2005;2(1):69.

163. Wang M, Cao R, Zhang L, Yang X, Liu J, $\mathrm{Xu} \mathrm{M}$, et al. Remdesivir and chloroquine effectively inhibit the recently emerged novel coronavirus (2019-nCoV) in vitro. Cell Res. 2020;30(3):269-71. 164. Singh AK, Singh A, Shaikh A, Singh R, Misra A. Chloroquine and hydroxychloroquine in the treatment of COVID-19 with or without diabetes: A systematic search and a narrative review with a special reference to India and other developing countries. Diabetes Metab Syndr. 2020;14(3):241-6.
How to cite this article: Zare A, SeyyedMahalle SFS, Mokhtari A, Pakdel N, Hamidi Z, Almasi-turk S, Baghban N, Khoradmehr A, Nabipour I, Behzadi MA, Tamadon A. An update of coronavirus disease 2019 (COVID19): an essential brief. Mod Med Lab J. 2021;4(1):19-38 